\title{
Perancangan E-Voting pemilihan Kepala Desa untuk Transparansi Informasi di Kecamatan Lueng Bata Kota Banda Aceh
}

\author{
Susmanto $^{1}$, Munawir $^{2 *}$, Erdiwansyah $^{3}$, Zulfan $^{4}$, Didik Setiyadi $^{5}$ \\ 1,2,3,4 Program Studi Teknik Komputer, Fakultas Teknik, Universitas Serambi Mekkah, Banda Aceh \\ ${ }^{5}$ Program Studi Informatika, Universitas Indonesia Mandiri \\ *Koresponden email: munawir@ serambimekkah.ac.id
}

Diterima: 3 November 2021

Disetujui: 7 Februari 2021

\begin{abstract}
The Village Government (geuchik), has a very important role in regulating and managing the interests of the community both in the village government and in the form of village head elections. Therefore, to create a clean and transparent village government in the election of the village head, in this study I will create an E-Voting program in the election of the village head. However, as time goes on and based on facts on the ground, what has been done so far, there are still many shortcomings and problems in data validation and the lack of knowledge and a high level of public emotionality in winning one candidate for village head, thus triggering conflict between residents, on the other hand the electoral system Conventionally, village heads can also be indicated as cheating. In an effort to avoid fraud in the village head election (Geuchik), an idea or idea is needed in the form of using technology based on the E-voting website and can be run using a computer or laptop device that has the E-Voting application installed so that it can be done transparently, effectively, efficient and professional that is expected in the election of the Village Head, in supporting E-Government in this study will be carried out in the Batoh Village (Gampong), Luengbata subdistrict, Banda Aceh City.
\end{abstract}

Keywords: $e$-voting, election, web programming, village head (geuchik), transparent

\begin{abstract}
Abstrak
Pemerintahan Desa (geuchik), mempunyai peran yang sangat penting dalam mengatur dan mengurus kepentingan masyarakat baik dalam pemerintahan Desa maupun dalam bentuk pemilihan kepala Desa. Oleh sebab itu untuk menciptakan pemerintahan Desa yang bersih transparan dalam pemilihan kepala Desa maka dalam penelitian ini saya akan membuat sebuah program E-Voting dalam pemilihan kepala Desa. Namun seiringnya waktu berjalan dan berdasarkan fakta di lapangan, selama ini masih banyak ditemukannya banyak kekurangan dan permasalahan dalam validasi data dan minimnya pengetahuan dan tingkat emosional masyarakat yang tinggi dalam memenangkan salah satu calon kepala desa. Hal ini memicu konflik antara warga dan disisi lain sistem pemilihan kepala desa secara konvensional sering terindikasi kecurangan. Dalam upaya menghindari kecurangan pemilihan kepala Desa (Geuchik) maka diperlukan suatu ide atau gagasan berupa penggunaan teknologi berbasis website e-voting. Teknologi ini dapat dijalankan dengan menggunakan perangkat komputer maupun laptop yang sudah terinstal aplikasi e-voting sehingga pemilihan dilakukan secara transparan, efektif, efisien dan profesional. Pemilihan kepala desa merupakan upaya dalam mendukung e-government dalam penelitian ini akan dilaksanakan pada Desa Batoh, kecamatan Lueng Bata Kota Banda Aceh.
\end{abstract}

Kata Kunci: e-voting, aplikasi, kepala desa (geuchik), pemilihan, transparan

\section{Pendahuluan}

Perkembangan teknologi di dunia sangat membantu dan memudahkan manusia dalam melakukan segala hal, salah satunya pemilihan dengan menggunakan suatu aplikasi atau yang biasa disebut dengan evoting. Di Indonesia, penggunaan e-voting hanya digunakan dalam skala terbatas, baik dalam lingkup organisasi, perusahaan maupun skala pemerintahan yang paling kecil yaitu dusun atau desa. Pada Tahun 2014 sesuai dengan penelitian yang telah dilakukan oleh Made, di Desa Mendoyo Dangin Tukad, Kabupaten Jembrana, Bali pernah melakukan pemilihan kepala desa dengan menggunakan aplikasi evoting dan telah disahkan oleh Mahkamah Konstitusi (MK) [1].

Pelaksanaan e-voting sudah pernah dilakukan di Indonesia, namun hanya beberapa desa saja yang sudah menerapkannya. Pemilihan dengan sistem e-voting belum pernah dilaksanakan di Provinsi Aceh namun peluang untuk penerapannya sangat terbuka luas. Khususnya desa Batoh, Kecamatan Lueng Bata pemilihan secara e-voting sangat cocok diterapkan secara menyeluruh. 
Proses pemilihan geuchik selama ini pada Desa Batoh dengan cara konvensional. Masyarakat yang akan memilih harus mendatangi tempat pemilihan atau Tempat Pemungutan Suara (TPS). Cara ini dianggap masih banyak kekurangan dikarenakan perlu waktu yang lama, biaya yang besar dan sulit dalam perhitungan suara. Pemilihan dilakukan untuk menentukan solusi yang terbaik dalam menyelesaikan masalah. Sistem pemilihan umum yang dikenal masyarakat adalah pemilihan atau Pilkada yang diselenggarakan oleh Komite Pemilihan Umum (KPU), namun kegiatan pemilihan biasanya dilakukan dalam skala yang lebih kecil, seperti pemilihan kepala desa. Pemilihan kepala desa biasanya dilaksanakan setelah masa jabatan kepala desa berakhir [2] [3].

Berdasarkan beberapa permasalahan yang telah diuraikan, maka perlu dibuatkan suatu sistem pemilihan yang bisa membantu pengerjaan pemilihan secara konvensional. Tujuan penelitian ini adalah untuk menerapkan metode e-voting dalam pemilihan Kepala Desa (Geuchik). Perangkat lunak yang dibangun ini akan menjadi keluaran yang dapat diterapkan oleh Pemerintahan Desa (Gampong) untuk mengatasi permasalahan dalam pemungutan suara berdasarkan data yang ada sesuai dengan jumlah pemilih yang diikutsertakan dalam pemilih kepala Desa.

\section{Metode Penelitian}

Dalam pembuatan rancangan aplikasi ini, metode yang digunakan berupa metode observasi. Observasi dilakukan untuk memperoleh data-data yang dibutuhkan dalam pembuatan perancangan aplikasi e-voting. Metode observasi ini berupa pengumpulan data dari sumber-sumber yang terkait dengan aplikasi yang akan dirancang yaitu aplikasi pemilihan kepala desa [4] [5] [6].

Prosedur pengolahan data ini, setelah semua data yang dibutuhkan telah terkumpul, selanjutnya datadata tersebut dipilah-pilah. Kemudian data yang telah disusun dimasukkan ke dalam perangkat lunak. Perangkat lunak berbasis Word Elektrik Browser (Web) ini didesain dengan menggunakan bahasa pemogramanan Personal Home Page (PHP) dan framewok CodeIgniter (CI) sehingga dapat di terapkan pada aplikasi e-voting dalam pemilihan Kepala Desa [7] [8] [9].

Mengidentifikasi masalah merupakan langkah pertama yang dilakukan dalam tahap analisis sistem. Masalah dapat didefinisikan sebagai suatu pertanyaan yang diinginkan untuk dipecahkan. Masalah inilah yang menyebabkan sasaran dari sistem tidak dapat dicapai. Berdasarkan permasalahan dalam pemilihan Kepala Desa yang sering kita jumpai yaitu masih adanya kecurangan dalam pengambilan suara atau permainan data pemilih, sehingga dalam penelitian ini membuat sebuah aplikasi e-voting yang akan di terapkan dalam pemilihan Kepala Desa yang baik dan membudayakan masyarakat cerdas dan bijak dalam pemilihan Kepala Desa [10] [11].

Jika pemerintah atau perusahaan dipandang berafiliasi terhadap partai atau kandidat tertentu, penggunaan mesin voting kemungkinan besar akan memicu kecurigaan kecurangan dalam pemilu [12]. Pemilih dapat memberikan suara tanpa batas dan tanpa terdeteksi oleh mekanisme apa pun dalam perangkat lunak pengumpul suara pemilih. Penulis memberikan gagasan cara untuk menghindari kecurangan dari mesin pemungutan suara elektronik dengan menerapkan sistem biometrik pada mesin pemungutan suara elektronik di pemilihan umum India [13] [14] [15]. E-voting tidak mengubah perilaku pemungutan suara dari orang-orang yang pada dasarnya tidak memilih dalam pemilihan, tetapi itu memberikan kesempatan partisipasi kepada orang-orang yang tidak punya waktu atau komitmen untuk pergi ke stasiun pemungutan suara [16] [17]. Gambar 1 memperlihatkan roadmap penelitian ini. 


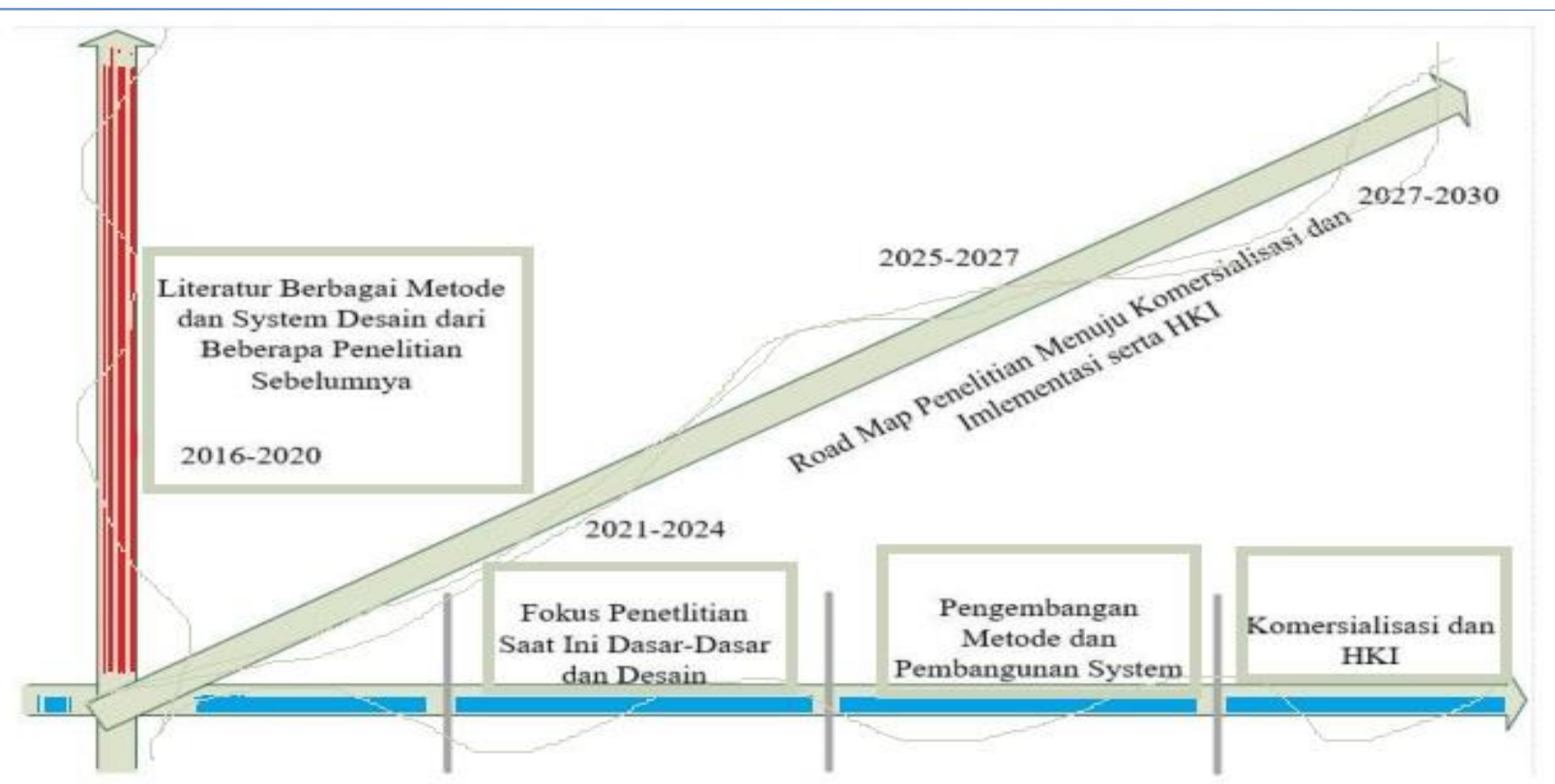

Gambar 1. Roadmap penelitian

Sumber : RIP Universitas, 2021

\subsection{Alat dan Bahan}

Pada Penelitian ini penulis memakai sebuah komputer pribadi baik itu untuk penulisan proposal skripsi maupun untuk membuat program sebagai hasil akhir pada penelitian ini. Adapun spesifikasi komputer tersebut adalah sebagai berikut. Processor : Intel Core i5-7200U2, VGA : Intel HD Grapich, RAM : 8 GB DDR3 (Minimal), Harddisk : 128 GB SSD dan Software atau perangkat lunak yang digunakan dalam penelitian ini di antaranya adalah : XAMPP untuk localhost, Visual Studio Code untuk editor, Framework Code Igniter, Browser sebagai media melihat hasil user Inteface

\subsection{Rancangan Sistem}

Pada tahap rancangan akan diuraikan tabel alur proses penelitian e-voting dan hasil perancangan akan diuraikan sebagai berikut pada flowchart Gambar 2.

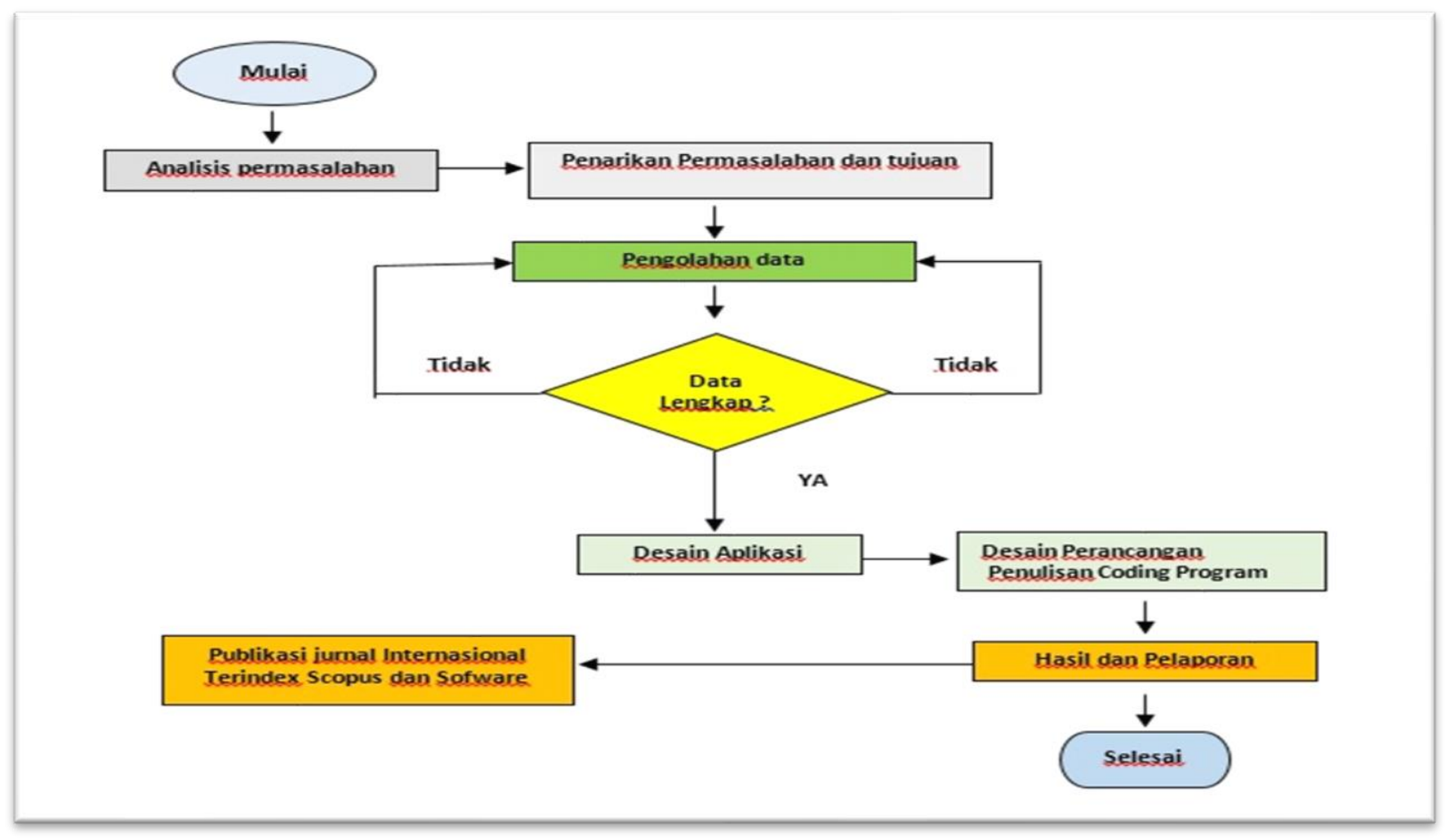

Gambar 2. Flowchart penelitian [18] 


\section{Hasil dan Pembahasan}

\subsection{Aplikasi Halaman Login}

Halaman Login ini berfungsi untuk masuk ke halaman berikutnya, yaitu dengan menginput username dan password dengan benar maka akan masuk ke halaman Admin. Sehingga user atau pengguna dapat melihat menu input dan output pada gambar. Login ini dapat dilihat pada Gambar 3.

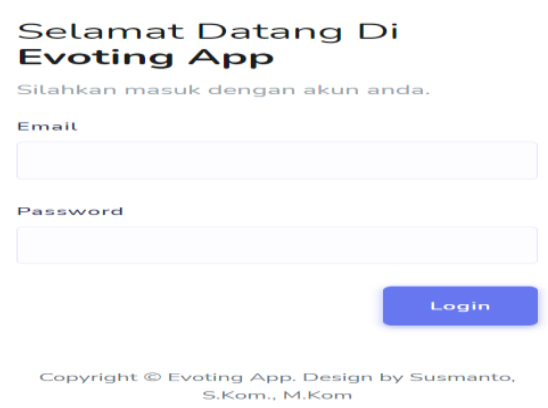

Gambar 3. Halaman login

Sumber : Hasil penelitian, 2021

\subsection{Dashboard Admin}

Dashboard Admin merupakan pusat kontrol dari aplikasi e-voting, data yang ada pada menu utama adalah lihat hasil, users, kandidat, pemilih, token dan setting. Pada form ini admin bisa melihat, mengedit dan menghapus data yang sudah ada. Terlihat pada Gambar $\mathbf{4}$ dashboard admin.

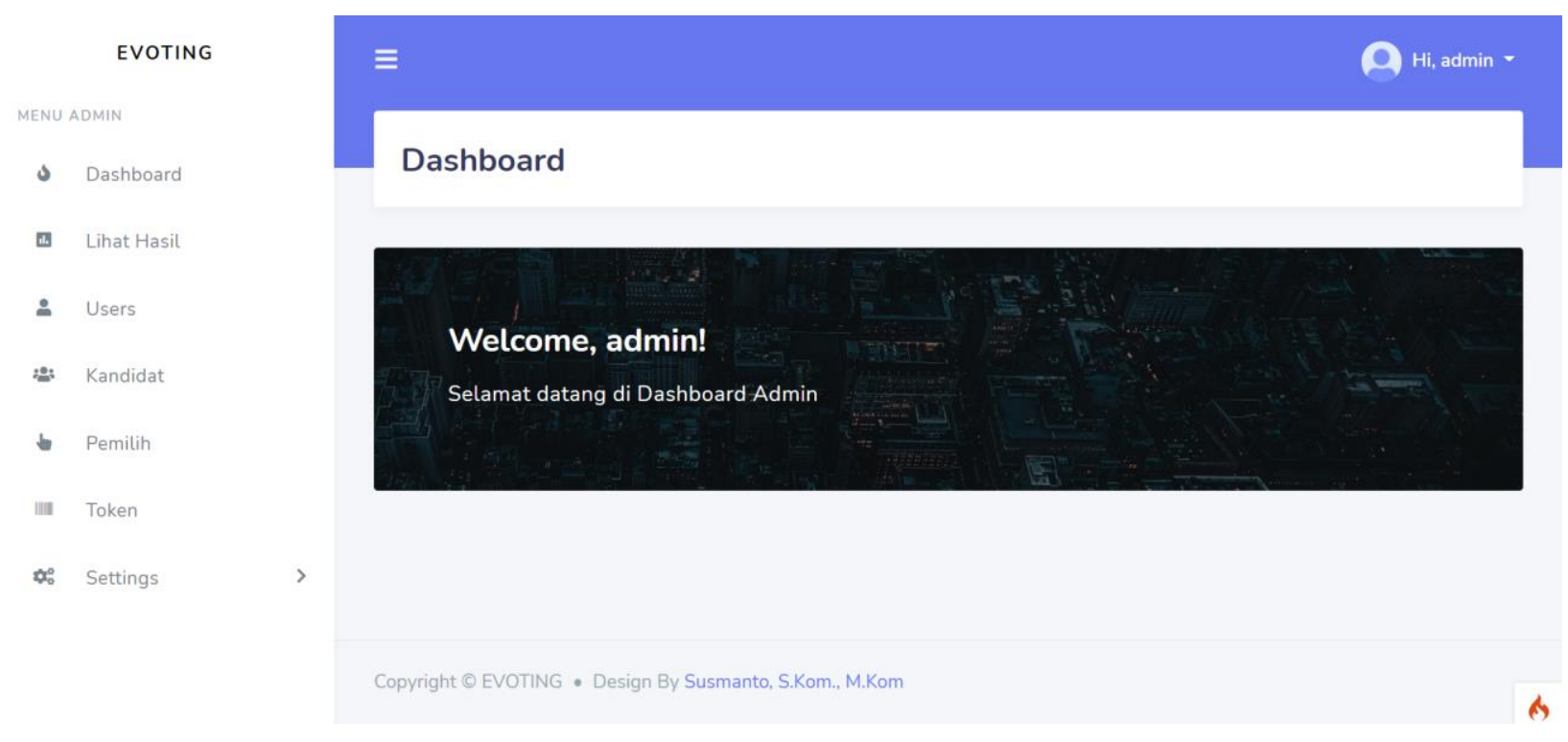

Gambar 4. Dashboard Admin

Sumber : Hasil penelitian, 2021

\subsection{Halaman Kandidat}

Halaman kandidat merupakan tabel untuk menginput nama kandidat dari calon geuchik di desa tersebut, dengan cara menginput nama, visi dan misi serta upload foto. Halaman kandidat ini dapat dilihat pada Gambar 5. 


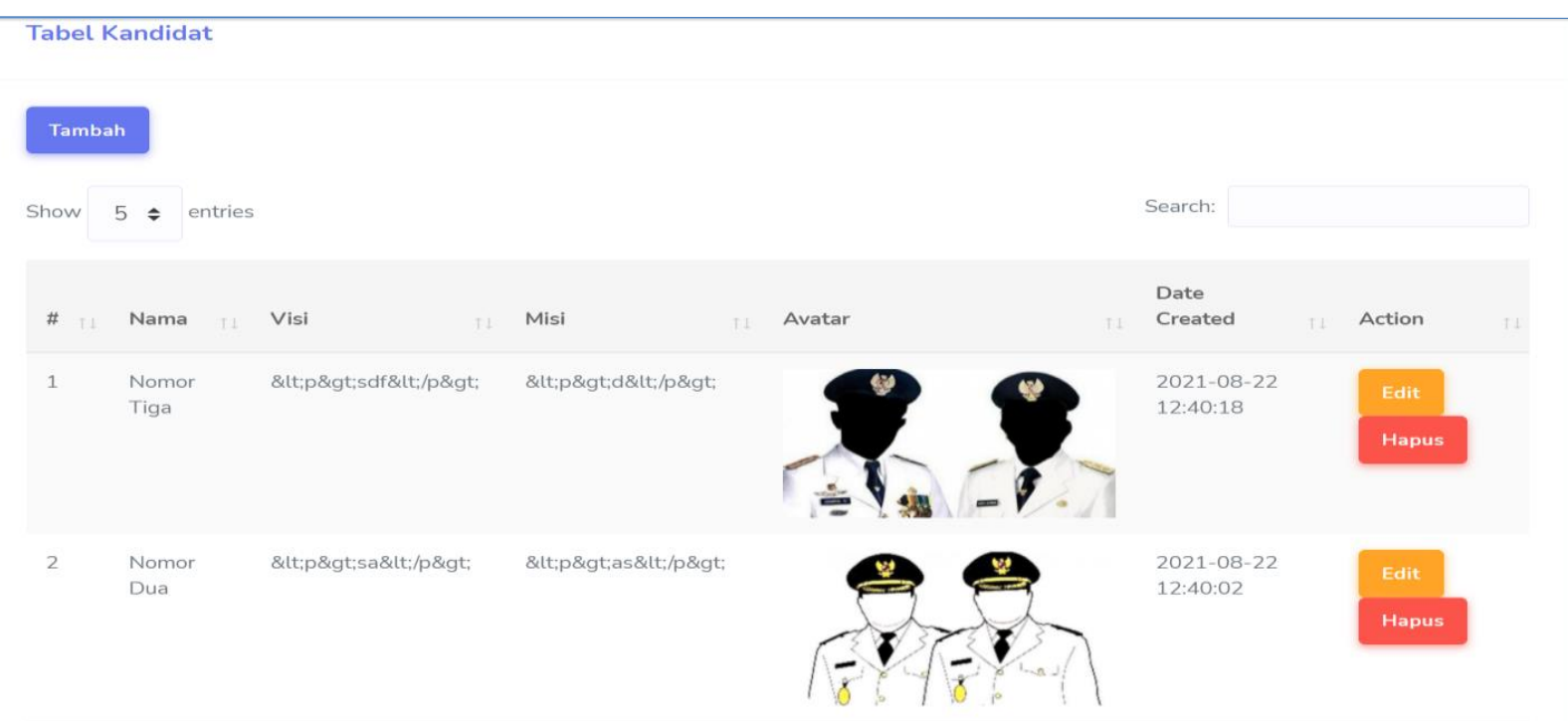

Gambar 5. Halaman Kandidat

Sumber : Hasil penelitian, 2021

\subsection{Halaman Create Token}

Halaman create token merupakan halaman input untuk dapat melakukan pemilihan oleh pemilih, jadi untuk memilih dari masing - masing kandidat atau calon geuchik terlebih dahulu harus memiliki token, jadi tidak sembarang orang bisa memilih. Halaman create token ini dapat dilihat pada Gambar 6.

\section{Token}

Tabel Token

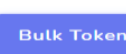

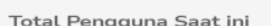

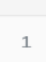

Expired At

2021-09-10 12:41:58

2021-09-10 12:41:58

2021-09-10 12:41:58

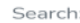

Date Created

2021-09-10 12:38:58

2021-09-10 12:38:58

2021-09-10 12:38:58
Action

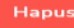

Hapus

Gambar 6. Halaman Create Token

Sumber : Hasil penelitian, 2021

\subsection{Halaman Pemilih}

Halaman pemilih berfungsi untuk data pemilih dari masing - masing desa dengan menentukan token masing - masing pemilih. Hanya pemilih yang terdata saja yang bisa memilih calon kandidat - kandidat yang telah ditentukan. Halaman create token ini dapat dilihat pada Gambar 7. 


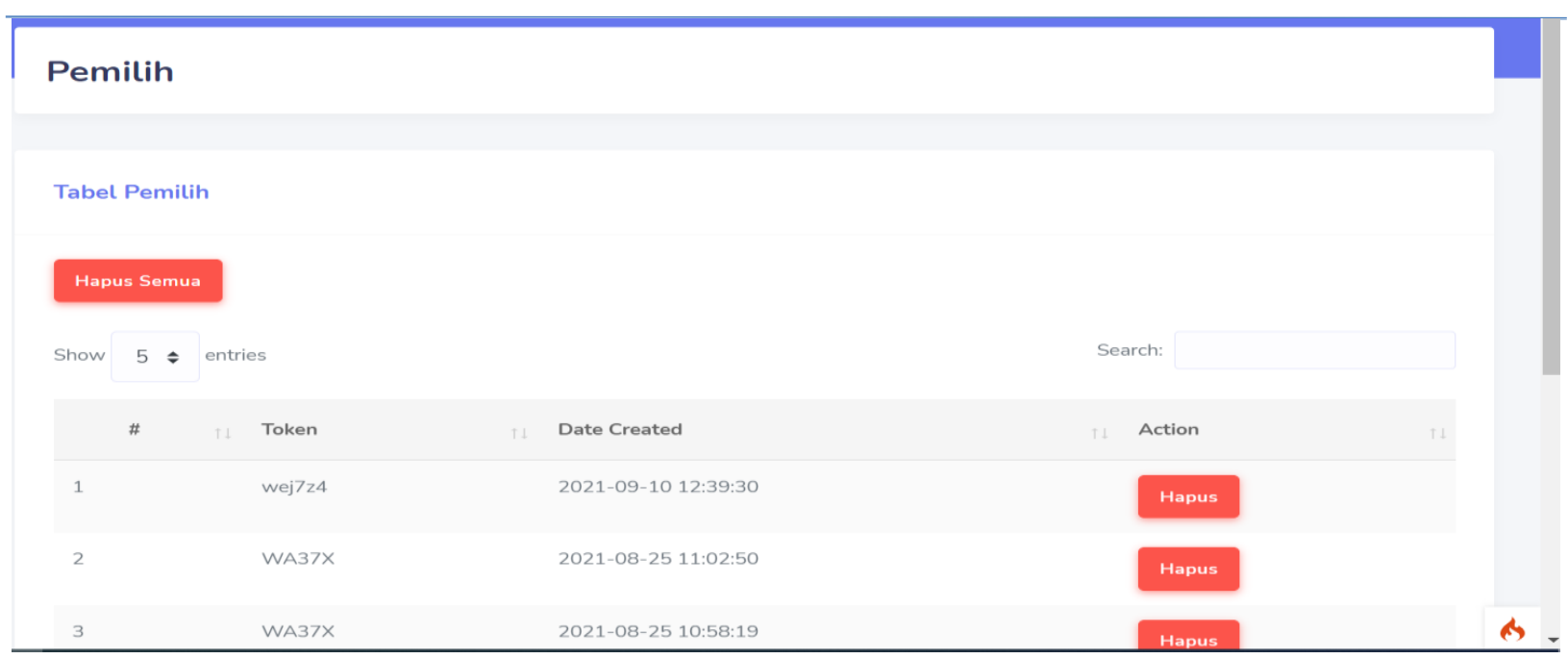

Gambar 7. Halaman pemilih

Sumber : Hasil penelitian, 2021

\subsection{Halaman Voting}

Halaman pemilih berfungsi untuk data pemilih dari masing - masing desa dengan menentukan token masing - masing pemilih. Hanya pemilih yang terdata saja yang bisa memilih calon kandidat - kandidat yang telah di tentukan. Halaman create token ini dapat dilihat pada Gambar 8.

\section{EVOTING PEMILIHAN KEUCHIK}

Selamat datang di aplikasi evoting, silahkan masukan token untuk memilih
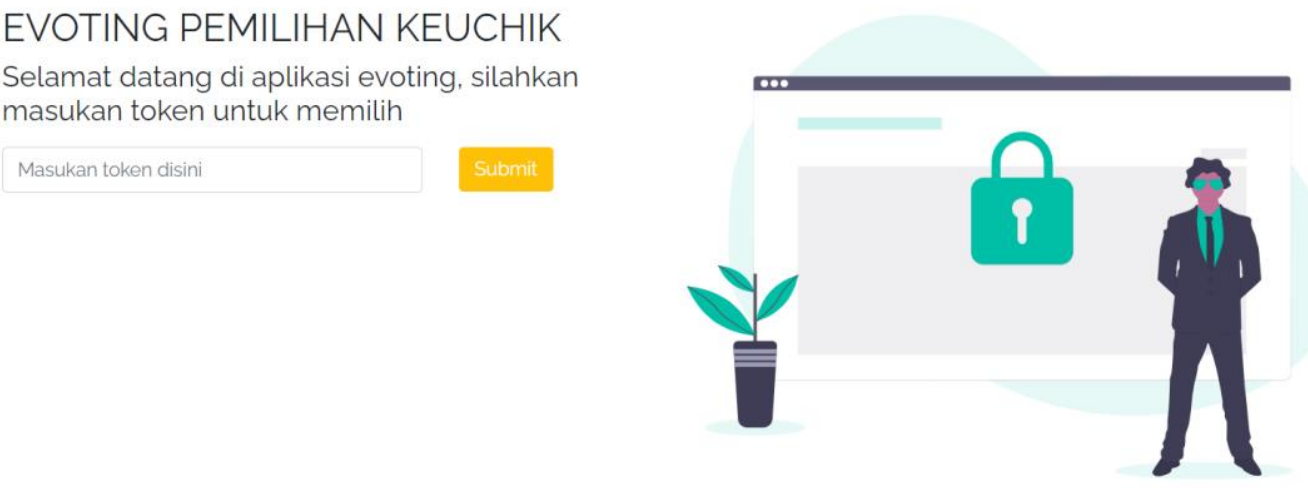

Page Load $0.0845 \mathrm{~s}$

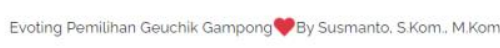

Gambar 8. Halaman pemilih

Sumber : Hasil penelitian, 2021

\subsection{Halaman Pilih Kandidat}

Halaman pilih kandidat merupakan halaman setelah token berhasil di isi oleh pemilih, kemudian pemilih tinggal memilih kandidat sesuai keinginan yang akan dijadikan geuchik. Cara pilihnya langsung tekan pilih kandidat selanjutnya data ini akan muncul di grafik hasil voting. Halaman pilih kandidat ini dapat dilihat pada Gambar 9. 


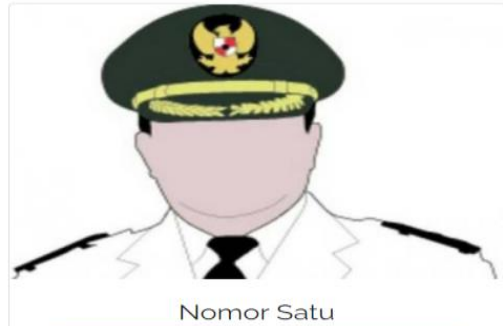

Pilih Kandidat Lihat Visi Misi

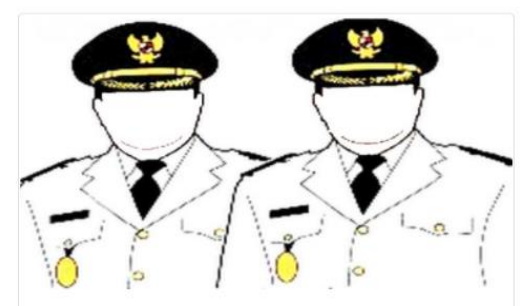

Nomor Dua

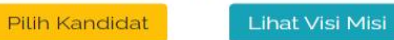

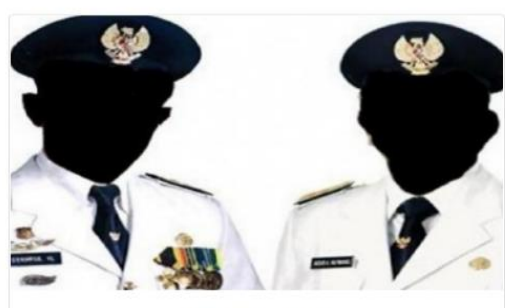

Nomor Tiga

Pilih Kandidat Linat Visi Misi

Gambar 9. Halaman Pemilih

Sumber : Hasil penelitian, 2021

\subsection{Halaman Hasil Voting}

Halaman hasil voting ini akan muncul pada login admin, jadi untuk melihat hasil pemilihan maka akan muncul grafik secara real time. Setiap pemilih memilih kandidatnya maka akan naik grafiknya sesuai yang di pilih pada calon tersebut. Halaman hasil voting ini dapat dilihat pada Gambar 10.

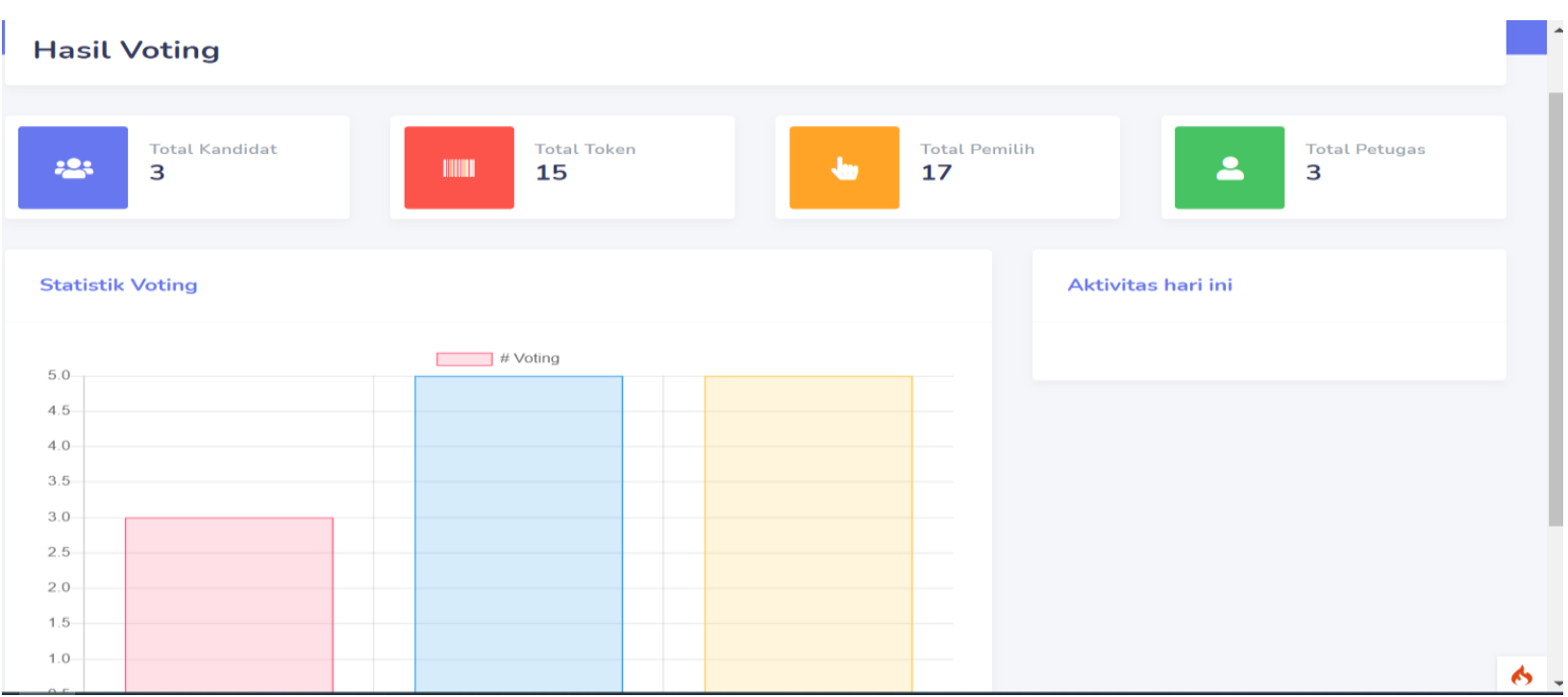

Gambar 10. Halaman hasil voting

Sumber : Hasil penelitian, 2021

\section{Kesimpulan}

Berdasarkan hasil perancangan sistem pemilihan Geuchik melalui e-voting di Kecamatan Lueng Bata, dilakukan simulasi aplikasi e-voting bersama masyarakat dan didampingi oleh Sekdes Desa Batoh. Setelah melakukan simulasi, maka mendapatkan data rekapan dengan cepat dan tepat, sehingga diharapkan pemilihan geuchik secara online ini dapat dilakukan secara transparan, efisien dan profesional. Pemilihan secara e-voting juga dapat dilakukan dalam waktu yang cepat dan biaya yang lebih murah dibandingkan dengan pemilihan secara konvensional.

\section{Daftar Pustaka}

1. Anistiawati, M. L. (2014). Implementasi Kebijakan Penerapan Elektronik Voting (E-Voting) Dalam Pemilihan Kepala Desa (Studi Kasus: Pemilihan Kepala Desa di Desa Mendoyo Dangin Tukad, Kecamatan Mendoyo Kabupaten Jembrana). Citizen Charter, 1(2), 165240. 
2. Fariyanto, F., Suaidah, S., \& Ulum, F. (2021). Perancangan Aplikasi Pemilihan Kepala Desa Dengan Metode Ux Design Thinking (Studi Kasus: Kampung Kuripan). Jurnal Teknologi Dan Sistem Informasi, 2(2), 52-60.

3. Yudha, R. K. (2021). Mekanisme Pemilihan Kepala Desa Dengan Menggunakan Sistem E-voting Di Desa L. Sidoharjo Kecamatan Tugumulyo Kabupaten Musirawas Sumatera Selatan. JUPANK (Jurnal Pancasila dan Kewarganegaraan), 1(1), 41-49.

4. Wati, y. (2021). Meningkatkan hasil belajar teks observasi dengan metode stad. Jupendik: jurnal pendidikan, 5(2), 43-48.

5. Sukardi, S. (2021). Analisa Minat Membaca Antara E-Book dengan Buku Cetak Menggunakan Metode Observasi Pada Politeknik Tri Mitra Karya Mandiri. IKRA-ITH EKONOMIKA, 4(2), 158-163.

6. Wibisono, M. R. (2021). Analisis jabatan menggunakan metode wawancara, kuesioner, observasi dan benchmarking pada pt xyz.

7. Mulyani, G., Zulhalim, Z., \& Yasin, V. (2021). Perancangan aplikasi e-persuratan berbasis web menggunakan framework codeigniter pada direktorat lalu lintas dan angkutan laut kementerian perhubungan. Journal of Information System, Applied, Management, Accounting and Research, 5(3), 546-557.

8. Kurniawan, D. W., \& Al Irsyadi, F. Y. (2021). Perancangan dan Pembuatan Aplikasi Manajemen Peminjaman Kendaraan berbasis Web dengan Framework Codeigniter. Emitor: Jurnal Teknik Elektro, 21(1), 49-53.

9. Syafitri, Y., Pramudya, Y. D., \& Rasid, M. (2021). Pemanfaatan Framework Codeigniter Untuk Membangun Aplikasi Display Produk di Alfamart Rajabasa. Jurnal Informasi dan Komputer, 9(1), 4552.

10. Adifia, R. (2021). E-voting dalam pemilihan walinagari kabupaten agam (studi kasus pemilihan walinagari kabupaten agam) (doctoral dissertation, Universitas Gadjah Mada).

11. Yudha, R. K. (2021). Mekanisme Pemilihan Kepala Desa Dengan Menggunakan Sistem E-voting Di Desa L. Sidoharjo Kecamatan Tugumulyo Kabupaten Musirawas Sumatera Selatan. JUPANK (Jurnal Pancasila dan Kewarganegaraan), 1(1), 41-49.

12. Putri, N. S., Hidayat, H., \& Romli, R. C. (2021). Isu Dinasti Politik pada Pilkada Serentak 2020 di Media Daring: Analisis Isi Pemberitaan Kompas. com. Jurnal Studi Jurnalistik, 3(2), 98-112.

13. Rahmatunnisa, M. (2021). Menyoal Politik Kekerabatan di Indonesia dalam Pelaksanaan Pilkada Serentak 2020. Jurnal Academia Praja, 4(2), 295-316.

14. Karmanis, K. (2021). Electronic Voting (E-Voting) Dan Pemilihan Umum (Studi Komparasi di Indonesia, Brazil, India, Swiss dan Australia). Mimbar Administrasi Fisip Untag Semarang, 18(2), 1124.

15. Ukhra, A., Hijri, Y. S., \& Taufikurrohman, I. (2021). Isu Politik Identitas dan Dinasti Politik dalam Kampanye Pilkada Serentak Tahun 2020. Jurnal Ilmiah Pendidikan Pancasila dan Kewarganegaraan, 6(2), 350-361.

16. Fakhranda, A. K. (2021). Perilaku memilih masyarakat dalam pemilihan kepala desa e-voting di Kelurahan Purwomartani Kapanewon Kalasan, Kabupaten Sleman, Daerah Istimewa Yogyakarta. Jurnal Sekolah Tinggi Pembangunan Masyarakat Desa.

17. Maryuni, S., \& Sitorus, R. L. (2021). Implementasi Kebijakan E-Voting Dalam Pemilihan Kepala Desa Di Kabupaten Mempawah Provinsi Kalimantan Barat. Jurnal Administrasi Publik dan Pembangunan, 2(1), 53-66.

18. Munawir (2019). Implementation of Information Portals in Lambeugak Village, Kuta Cot Glie, Aceh Besar District, Aceh Province. In Journal of Physics: Conference Series (Vol. 1232, No. 1, p. 012024). IOP Publishing. 